\title{
Variation in strong interactions in the intertidal zone along a geographical gradient: a Washington-Alaska comparison
}

\author{
Megan N. Dethier*, David O. Duggins \\ Friday Harbor Laboratories, University of Washington, Friday Harbor, Washington 98250, USA
}

\begin{abstract}
Identical and simultaneous experiments involving the removal of an abundant herbivore, the chiton Katharina tunicata, were performed in the low intertidal zone in Washington and southeast Alaska. While in Washington this manipulation resulted in dramatic changes in community structure, in Alaska there was little coupling between $K$. tunicata and other community components over the same 3 yr interval. A persistent intertidal kelp bed developed in Washington in the absence of $K$. tunicata, whereas in Alaska kelp abundance was highly variable, and unrelated to chiton abundance. This difference was probably attributable to the predominance of a perennial kelp in Washington and an annual kelp at the Alaskan site. Limpets declined in abundance following chiton removal in both regions, but the increase in abundance and diversity of other algae that occurred in Washington did not take place in Alaska. Our experiments show that the presence of a strong interaction in one region does not guarantee its existence in another, even if community composition is very similar in the 2 locales.
\end{abstract}

\section{INTRODUCTION}

Ecological communities are frequently structured by the interactions of a few key species. However, while field studies from a wide range of habitats have demonstrated the existence of such strong interactions (sensu Paine 1980), little attention has been focused on variation in their importance over large spatial or temporal scales. For example, although the starfish Pisaster ochraceus can determine species diversity and individual species distribution along the coast of Washington state (Paine 1966, 1974), its role is unknown closer to the geographical edge of its range in California or Alaska. Hairston (1980) showed that the intensity of competition between 2 salamander species varies markedly in 2 geographic regions. Wiens (1977) suggested that competition among birds may be a critical structuring parameter during 'bottleneck' years but be relaxed at other times, and Dunham (1980) showed temporal variation in lizard competition. Similarly, paleontologists must consider whether interactions that are strong today were important in determining paleoassem-

\footnotetext{
- Friday Harbor Laboratories and Institute for Environmental Studies
}

blages and the direction of evolution. Palumbi (1985) notes that variation in ecological interactions at even a local scale can influence the evolution of the organisms involved. Factors leading to variation in strong interactions over spatial or temporal scales thus are clearly of importance to our understanding of both terrestrial and marine community structure, and to the evolution of ecological interactions.

Along the wave-exposed, rocky intertidal zone of the northeast Pacific Ocean resides an assemblage of herbivores composed primarily of limpets and chitons, but also including other snails, sea urchins, crustaceans, and fishes. These herbivores, as well as many of the other plant and animal species in this habitat, are quite consistent along a broad geographic range, with many of the species co-occurring from the northern Gulf of Alaska to central California. At many sites, limpet and chiton populations attain high densities, and in the case of one chiton species, high biomass (Dethier \& Duggins 1984).

This paper presents the results of field experiments and observations examining the ecological role of the most conspicuous herbivore in mid and low zones, the chiton Katharina tunicata (hereafter called Katharina). Previous papers quantified the effect of grazing by 
Katharina in the center of its geographical range (Duggins \& Dethier 1985), and the ecological relationship between Katharina and other grazers (Dethier \& Duggins 1984). These experiments showed that in Washington, Katharina is a 'strong interactor' relative to both benthic algae and limpets. We are concerned here with 2 questions: (1) what is the ecological role of Katharina near the northern limit of its range? and (2) what accounts for the difference in this role at 2 sites that differ greatly in geographic latitude but only subtly in floral and faunal composition?

\section{METHODS AND DATA ANALYSIS}

The data in this paper were gathered at Torch Bay, Alaska $\left(58^{\circ} 20^{\prime} \mathrm{N}, 136^{\circ} 50^{\prime} \mathrm{W}\right)$ in the mid to low intertidal zone (ca +1 to $-1 \mathrm{~m}$ relative to Mean Lower Low Water). See Duggins (1980) and Palumbi (1986) for descriptions of the site. Observations and experiments followed the same procedures as used for our comparable study at Pile Point on San Juan Island, Washington, and were performed over the same time period (spring 1979 through summer 1983: see Duggins \& Dethier 1985 for details). Wave exposure at Torch Bay is probably greater than at Pile Point, although both sites would be classified as moderately exposed (Ricketts \& Calvin 1968).

Species lists of organisms present in the mid-low zone at both sites were generated from quadrat data (described below) and from inspection of areas adjacent to quadrats. We determined the diet of Katharina by collecting individuals from a variety of areas and examining fresh gut contents. Size distributions were assessed by measuring all individuals from haphazardly selected $0.1 \mathrm{~m}^{2}$ quadrats in the upper and lower halves of the intertidal range of Katharina. Chiton and limpet biomasses were estimated from sizes and densities in quadrats, using data on size-mass relationships from Menge (pers. comm.): Katharina log dry wt $(\mathrm{g})=3.017 \mathrm{log}$ length $(\mathrm{cm})-2.209$; Lottia pelta $\log w t=3.516 \log$ length $-2.010 ;$ L. strigatella log $w t$ $=2.672 \mathrm{log}$ length $-1.773 ;$ Tectura scutum log wt $=$ 3.011 log length - 2.064 (equations in Menge 1972 are incorrect).

The role of Katharina in Torch Bay was evaluated by removing all individuals from two $25 \mathrm{~m}^{2}$ areas (sites). We chose these areas (separated by approximately $1 \mathrm{~km}$ ) for similarity of flora and fauna, but small differences did exist. Experiments were begun at Site $A$ in June 1979 and at Site B in July 1980. At each site, we marked and censused 8 haphazardly chosen permanent $0.1 \mathrm{~m}^{2}$ quadrats, then removed all the Katharina (ca 2000 from Site A, 1800 from Site B). A control area with similar initial Katharina densities and similar marked quadrats was established within $50 \mathrm{~m}$ of each removal site. All quadrats were subsequently censused each year in early spring and again in summer, and chitons were removed again at these times. We found that Katharina moved back into these areas only slowly, so that the cleared areas remained free of chitons (see below) without the use of cages.

The great logistic difficulty in reaching and working in Torch Bay, along with the time-consuming startup and maintenance procedures of these experiments, resulted in our inability to replicate the experiment at more than 2 sites. To test for treatment effects due to the removal of Katharina we examined changes over time ( $3 y r)$ in the permanent quadrats at each of the 4 areas, and used these changes (untransformed data) as samples in a Kruskal-Wallis 1 -way ANOVA with 3 d.f. A posteriori multiple comparisons were performed with a nonparametric Newman-Keuls test (Zar 1974). We have reanalyzed our Washington data in an identical fashion for comparison, although multiple comparisons were not possible because of unequal sample sizes ( $N=10$ at one area, $N=8$ at the others). In addition, we present the means and standard deviations of all the data at Year 0 and Year 3 for visual assessment of differences between treatments.

\section{RESULTS}

The intertidal assemblages at Torch Bay and Pile Point are similar in species composition and general abundance (Table 1), despite their separation by over $1400 \mathrm{~km}$. The only striking difference between the mid-low intertidal organisms in the 2 regions is in the abundance of the kelp Hedophyllum sessile. At Pile Point this is the dominant alga, while at Torch Bay the kelp Alaria marginata predominates and Hedophyllum is very rare (it occurs in adjacent bays off the Gulf of Alaska, but is patchy in its distribution). Katharina densities were similar in the experimental areas at Pile Point (28 to $52 \mathrm{~m}^{-2}$ ) and Torch Bay (21 to $57 \mathrm{~m}^{-2}$ ), although overall biomass at Pile Point was somewhat higher (Fig. 1) because more of the individuals were smaller at Torch Bay $(48 \%<4 \mathrm{~cm})$ than at Pile Point (10\%). Other differences between the Washington and Alaska sites are subtle; e.g. the sessile polychaete Dodecaceria fewkesi was relatively common (mean of about $4 \%$ cover) at Pile Point but absent in Torch Bay, while the sponge Halichondria panicea and articulated coralline algae were more abundant at Torch Bay (overall mean percent covers of ca 6 and $15 \%$, respectively, versus rare and $8 \%$ at Pile Point). Other differences (Table 1) occurred only in sessile organisms occupying little area, or mobile organisms seen seldom in the study sites. 
Table 1. Common mid- and low-intertidal organisms in Torch Bay, Alaska and Pile Point, Washington (USA). O: absent, R: rare, C: common. Some of the 'rare' species are common in other zones. Non-destructive field sampling prevented the identification to species of a number of groups; these are listed as functional groupings of taxa (e.g. crustose corallines)

\begin{tabular}{|c|c|c|c|c|c|}
\hline & $\begin{array}{c}\text { Torch } \\
\text { Bay }\end{array}$ & $\begin{array}{l}\text { Pile } \\
\text { Point }\end{array}$ & & $\begin{array}{c}\text { Torch } \\
\text { Bay }\end{array}$ & $\begin{array}{l}\text { Pile } \\
\text { Point }\end{array}$ \\
\hline \multicolumn{6}{|l|}{ Plants } \\
\hline Phaeophyta & & & Asteroids & & \\
\hline Alaria marginata & $\mathrm{C}$ & $\mathrm{C}$ & Henricia leviuscula & $\mathrm{C}$ & $\mathrm{C}$ \\
\hline Laminaria groenlandica & $\mathrm{R}$ & $\mathrm{R}$ & Evasterias troschelii & $\mathrm{C}$ & $\mathrm{R}$ \\
\hline Costaria costata & $\mathrm{R}$ & $\mathrm{R}$ & Pycnopodia helianthoides & $\mathrm{C}$ & $\mathrm{R}$ \\
\hline Hedophyllum sessile & $\mathrm{R}$ & $\mathrm{C}$ & \multirow{2}{*}{$\begin{array}{l}\text { Holothuroids } \\
\text { Cucumaria pseudocurata }\end{array}$} & \multirow{3}{*}{$\mathrm{C}$} & \multirow{3}{*}{$\mathrm{R}$} \\
\hline Lessoniopsis littoralis & $\mathrm{R}$ & O & & & \\
\hline $\begin{array}{l}\text { Nereocystis leutkeana } \\
\text { Fucus spp. }\end{array}$ & $\begin{array}{l}\mathrm{R} \\
\mathrm{C}\end{array}$ & $\begin{array}{l}\mathrm{R} \\
\mathrm{C}\end{array}$ & Urchins & & \\
\hline Ralfsia pacifica & $\mathrm{C}$ & $C$ & Strongylocentrotus droebachiensis & $\mathrm{C}$ & $\mathrm{C}$ \\
\hline \multicolumn{3}{|l|}{ Rhodophyta } & S. purpuratus & $\mathrm{C}$ & $\mathrm{C}$ \\
\hline Iridaea spp. & $\mathrm{C}$ & $\mathrm{C}$ & Chitons & & \\
\hline Odonthalia floccosa & $C$ & C & Katharina tunicata & $\mathrm{C}$ & $\mathrm{C}$ \\
\hline Microcladia sp. & $\mathrm{C}$ & $\mathrm{C}$ & Tonicella lineata & $\mathrm{C}$ & $\mathrm{C}$ \\
\hline Neorhodomela larix & $\mathrm{C}$ & $\mathrm{C}$ & Sm. unidentified chitons & $\mathrm{C}$ & C \\
\hline Polysiphonia spp. & C & $\mathrm{C}$ & Mopalia spp. & $\mathrm{C}$ & $\mathrm{C}$ \\
\hline Callithamnion pikeanum & C & C & Cryptochiton stelleri & $\mathrm{C}$ & $\mathrm{C}$ \\
\hline Halosaccion glandiforme & $\mathrm{C}$ & C & \multicolumn{3}{|l|}{ Limpets } \\
\hline Porphyra spp. & C & $\mathrm{C}$ & Acmaea mitra & C & C \\
\hline Gigartina/Mastocarpus spp. & $\mathrm{C}$ & $\mathrm{C}$ & $\begin{array}{l}\text { Acmaea mitra } \\
\text { Lottia pelta }\end{array}$ & $\mathrm{C}$ & c \\
\hline 'Petrocelis middendorffii' & $\mathrm{C}$ & $\mathrm{C}$ & $\begin{array}{l}\text { Lottla pelta } \\
\text { L. strigatella }\end{array}$ & C & c \\
\hline Corallina vancouveriensis & C & C & $\begin{array}{l}\text { L. stngatella } \\
\text { Tectura scutum }\end{array}$ & $\mathrm{C}$ & c \\
\hline Bossiella spp. & $\mathrm{C}$ & $\mathrm{C}$ & $\begin{array}{l}\text { Iectura scutum } \\
\text { Diodora aspera }\end{array}$ & $\mathrm{C}$ & c \\
\hline Calliarthron tuberculosum & $C$ & C & & & C \\
\hline Crustose corallines & C & C & \multicolumn{3}{|l|}{ Snails } \\
\hline Hildenbrandia spp. & C & $\mathrm{C}$ & Lacuna spp. & C & $\mathrm{C}$ \\
\hline Other foliose red algae & $\mathrm{C}$ & $\mathrm{C}$ & Margarites spp. & C & $\mathrm{C}$ \\
\hline & Thais (Nucella) emarginata & $\mathrm{C}$ & $\mathrm{C}$ \\
\hline $\begin{array}{l}\text { Unioropnyta } \\
\text { Ulvoids }\end{array}$ & $\mathrm{C}$ & $\mathrm{C}$ & I lamellosa & $\mathrm{C}$ & C \\
\hline Acrosiphonia 5pp. & C & $\mathrm{C}$ & $T$ canaliculata & C & $\mathrm{C}$ \\
\hline Benthic diatoms & & & $T$ lima & C & $\mathrm{C}$ \\
\hline $\begin{array}{l}\text { Benthic diatoms } \\
\text { Phyllospadix scouleri }\end{array}$ & C & $\mathrm{C}$ & \multicolumn{3}{|l|}{ Opisthobranchs } \\
\hline Phyllospadix scoulen & C & C & Onchidella borealis & $\mathrm{C}$ & C \\
\hline \multicolumn{3}{|l|}{ Animals } & Archidoris montereyensis & $\mathrm{C}$ & $\mathrm{C}$ \\
\hline Sponges & & & \multicolumn{3}{|l|}{ Mussels } \\
\hline Halichondria panicea & C & C & Mytilus edulis & $\mathrm{C}$ & C \\
\hline Ophlitaspongia pennata & $\begin{array}{l}\mathrm{C} \\
\mathrm{C}\end{array}$ & $\begin{array}{l}\mathrm{C} \\
\mathrm{C}\end{array}$ & M. californianus & $\mathrm{R}$ & $\mathrm{R}$ \\
\hline Anemones & & & \multicolumn{3}{|l|}{ Barnacles } \\
\hline Anthopleura elegantissima & 0 & $\mathrm{C}$ & Semibalanus cariosus & C & $\mathrm{C}$ \\
\hline A. xanthogrammica & $\mathrm{C}$ & $\mathrm{R}$ & Balanus glandula & $\mathrm{C}$ & $\mathrm{C}$ \\
\hline Metridium senile & C & $\begin{array}{l}\mathrm{K} \\
\mathrm{R}\end{array}$ & B. nubilus & C & $\mathrm{R}$ \\
\hline Other anemones & $\mathrm{C}$ & $\hat{R}$ & Chthamalus dalli & $\mathrm{C}$ & $\mathrm{C}$ \\
\hline \multicolumn{3}{|l|}{ Bryozoans } & \multirow{2}{*}{\multicolumn{3}{|c|}{$\begin{array}{l}\text { Crabs } \\
\text { Oedignathus inermis }\end{array}$}} \\
\hline Encrusting bryozoans & C & $\mathrm{R}$ & & C & $\mathrm{C}$ \\
\hline Flustrella $\mathrm{sp}$ & $\mathrm{C}$ & $\mathrm{R}$ & Polychaetes & & \\
\hline \multicolumn{3}{|l|}{ Asteroids } & Dodecaceria fewkesi & $\mathrm{R}$ & $\mathrm{C}$ \\
\hline Pisaster ochraceus & C & $\mathrm{C}$ & Ascidians & & \\
\hline Leptasterias hexactis & $\mathrm{C}$ & $\mathrm{C}$ & Styela spp. & $\mathrm{C}$ & $\mathrm{C}$ \\
\hline
\end{tabular}

As in Washington, Katharina in Torch Bay are trophic generalists, eating a wide range of prey including bladed and filamentous algae, articulated corallines, kelp, and small sessile invertebrates. At both sites, diatoms are a major component of their diet (Table 2).
Diets seen in Torch Bay may be more generalized because many more individuals were examined, or because a greater diversity of algae is available in the low zone. A qualitative survey at Torch Bay suggested that Katharina were consuming algae roughly in pro- 
Table 2. Katharina tunicata. Gut contents of chitons from Torch Bay ( $N=76$ individuals examined) and Pile Point $(N=$ 25). Data represent percentages of individuals whose principal food item (by volume in the gut) was in that category

\begin{tabular}{lcc|}
\hline Taxon & Pile Point & Torch Bay \\
\hline Diatoms & 68 & 16 \\
Articulated corallines & 4 & 25 \\
Polysiphonia spp. & 24 & 5 \\
Kelp blades & 0 & 13 \\
Other algae & 4 & 22 \\
Halichondria & 0 & 12 \\
Small barnacles & 0 & 7 \\
\hline
\end{tabular}

portion to their abundance (own unpubl. obs.). In the low zone at Pile Point, Katharina have such a strong inhibitory effect on algae (Duggins \& Dethier 1985) that there are few macroscopic plants available for consumption, and few found in their diets.
Size distributions at different tidal heights were also similar in Washington and Alaska; smaller Katharina were found consistently in the upper half of their intertidal range (e.g. sizes of 50 neighboring chitons in the upper half of Site B $=3.9 \pm 1.9 \mathrm{~cm}$, of 53 in the lower half $=6.1 \pm 2.0 \mathrm{~cm}$ : cf. data in Duggins \& Dethier 1985).

Given the similarities between communities in Washington and Alaska, we anticipated similar community responses to the removal of Katharina. In Washington, the removal of Katharina leads to rapid and dramatic changes (for temporal sequence see Dethier and Duggins 1984) in a number of community parameters (Table 3, Figs. 1 to 3); but in Torch Bay, the same manipulation had few consistent effects (Table 3 , Figs. 1 to 3). This lack of predictable response in Torch Bay was not the result of failure to effectively remove the chitons; chiton biomasses remained at $<10 \%$ of their pre-manipulation level throughout the 3 to 4 yr

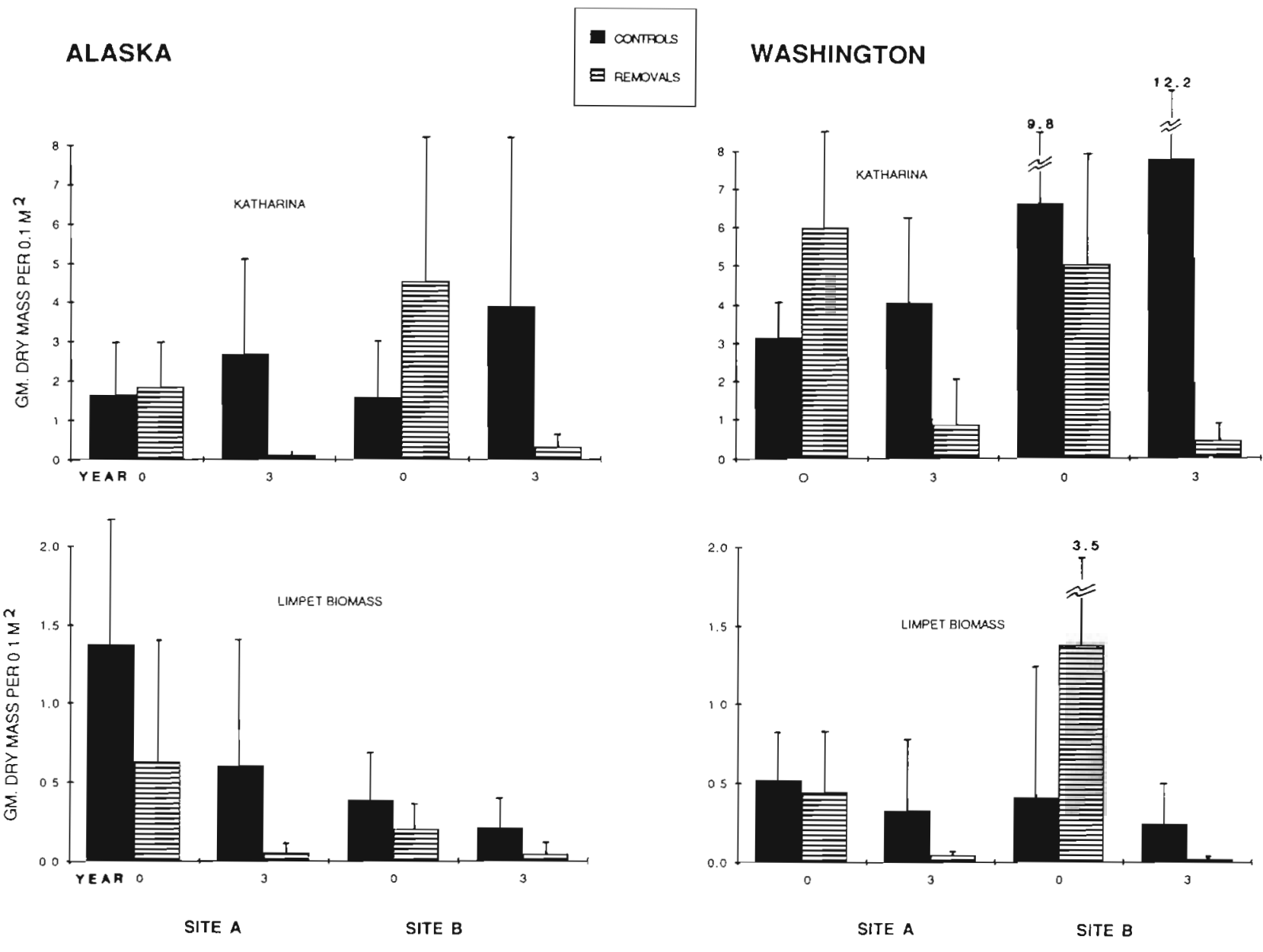

Fig. 1 Biomasses (g dry biomass per $0.1 \mathrm{~m}^{2}$ ) of Katharina tunicata and of limpets (all species combined) in experimental and control areas at the beginning (Year 0) and end (Year 3) of the manipulations. Means and 1 SD. $N=8$ for each bar $\mathrm{txcept}$ for Washington site $\mathrm{A}$, where $N=10$ 
that the experiment ran. At Pile Point, where immigrants tended to be large rather than small chitons, our efficacy of removal was actually slightly less (range of 3.5 to $10.1 \%$ of original biomass over the 4 yr: Fig. 1).

The most dramatic response to the removal of Katharina in Washington was the rapid transformation of the low intertidal zone into a dense kelp bed of Hedophyllum sessile, Alaria marginata, Nereocystis luetkeana, and small amounts of other species. Although the control areas also underwent increases
(Table 3), these increases were much smaller than in the chiton removals. In Alaska, while there were large changes in the abundance of kelps (primarily Alaria marginata, with small quantities of Laminaria groenlandica), these changes were not related to the presence or absence of Katharina (Table 3). The ANOVA in Alaska is significant not because of a treatment effect (as in Washington), but because the brown algae in both treatments at Site A increased (Fig. 2). A. marginata, which is an annual, undergoes large seasonal and year-

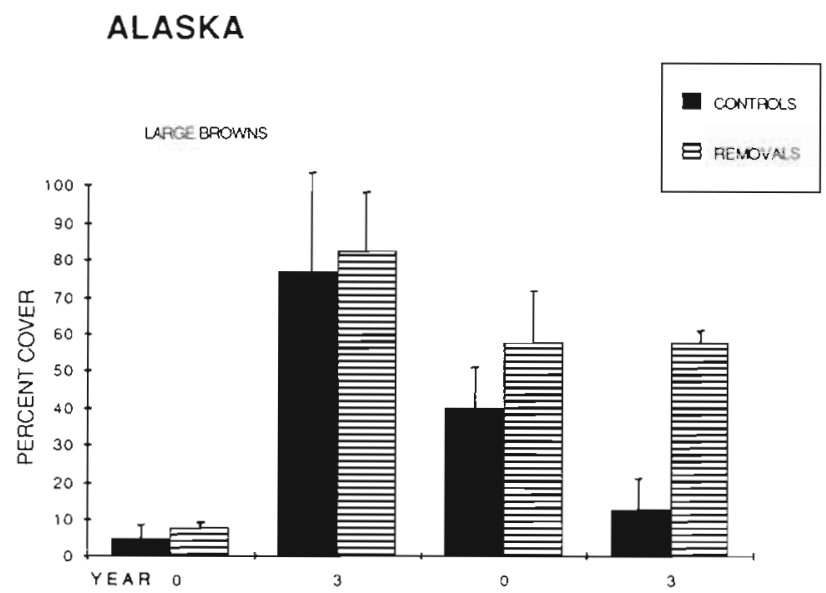

\section{WASHINGTON}
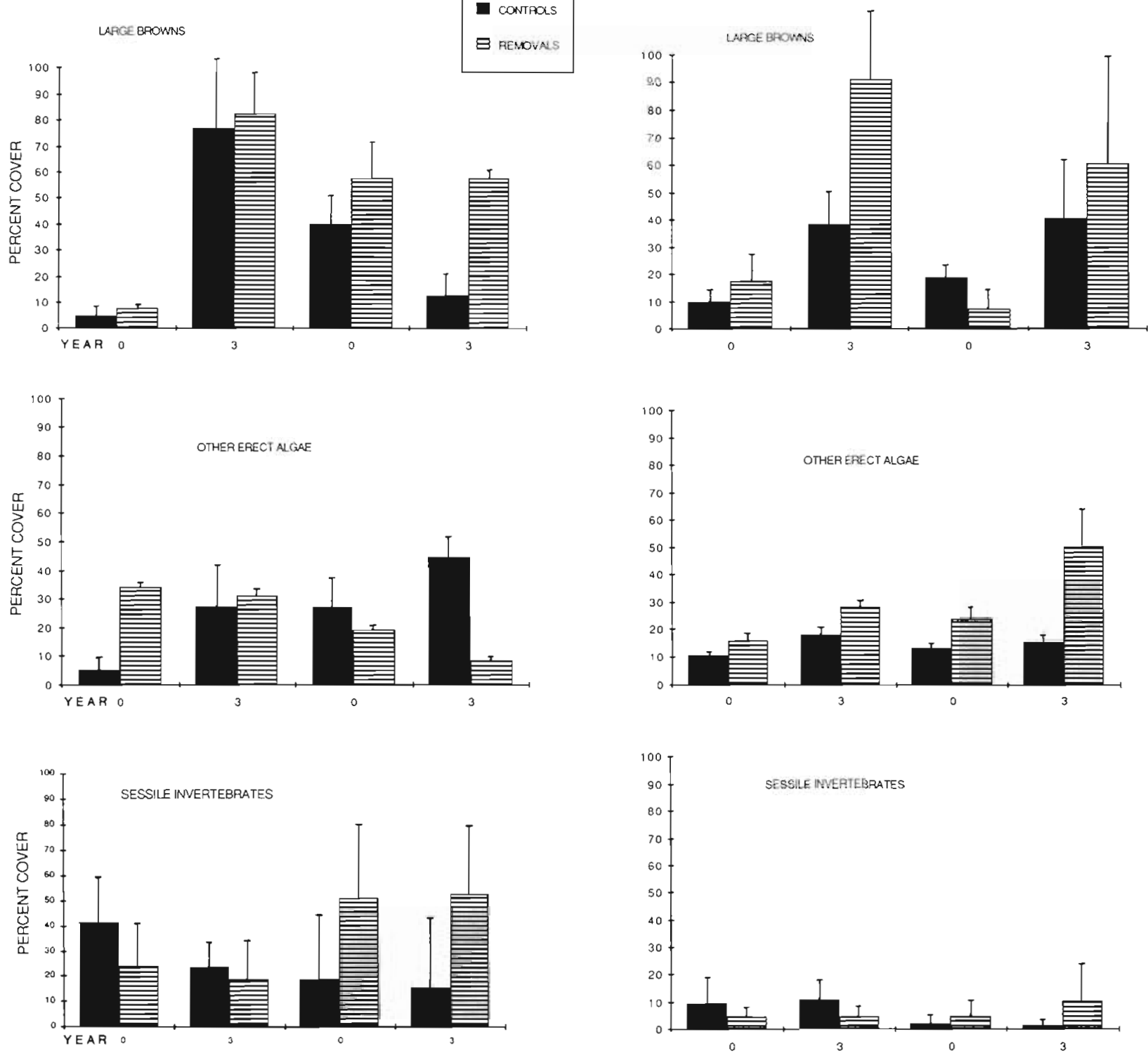

SITE A

SITE B

SITE A

SITE B

Fig. 2. Percent covers of algae and invertebrates in experimental and control areas. Means and 1SD calculated for arcsinetransformed data, and back-transformed for illustration. $N$ as in Fig. 1 
Table 3. Mean changes between Year 0 and Year 3 in each of the 5 parameters monitored in Alaska and Washington. Significance values given for 1-way non-parametric ANOVAs testing for differences among the 4 areas in each region. The same adjacent letter indicates that values in a column are not significantly different from one another See text and figure captions for explanations of the parameters

\begin{tabular}{|c|c|c|c|c|c|}
\hline & $\begin{array}{c}\% \text { Cover } \\
\text { brown algae }\end{array}$ & $\begin{array}{l}\% \text { Cover } \\
\text { other algae }\end{array}$ & $\begin{array}{c}\text { Algal } \\
\text { richness }\end{array}$ & $\begin{array}{c}\text { Algal } \\
\text { diversity }\end{array}$ & $\begin{array}{c}\text { Limpet } \\
\text { biomass }\end{array}$ \\
\hline \multicolumn{6}{|l|}{ Alaska } \\
\hline Removal A & $+66 a$ & $-3 c$ & -1.4 & -0.07 & -0.59 \\
\hline Removal B & $+3 b$ & $-10 c$ & -2.2 & -0.17 & -0.15 \\
\hline Control A & $+63 a$ & $+22 d$ & -1.6 & -0.17 & -0.77 \\
\hline Control B & $-23 b$ & $+14 d$ & -1.4 & +0.02 & -0.17 \\
\hline$p=$ & .0002 & .008 & .73 & .06 & .45 \\
\hline \multicolumn{6}{|l|}{ Washington } \\
\hline Removal A & +91 & +13 & +4.3 & +0.14 & -0.40 \\
\hline Removal B & +51 & +22 & +4.4 & +0.28 & -1.37 \\
\hline Control A & +30 & +9 & +2.1 & -0.06 & -0.19 \\
\hline Control B & +19 & +1 & +1.1 & +0.04 & -0.17 \\
\hline$p=$ & .04 & .42 & .01 & .07 & .03 \\
\hline
\end{tabular}

\section{ALASKA}
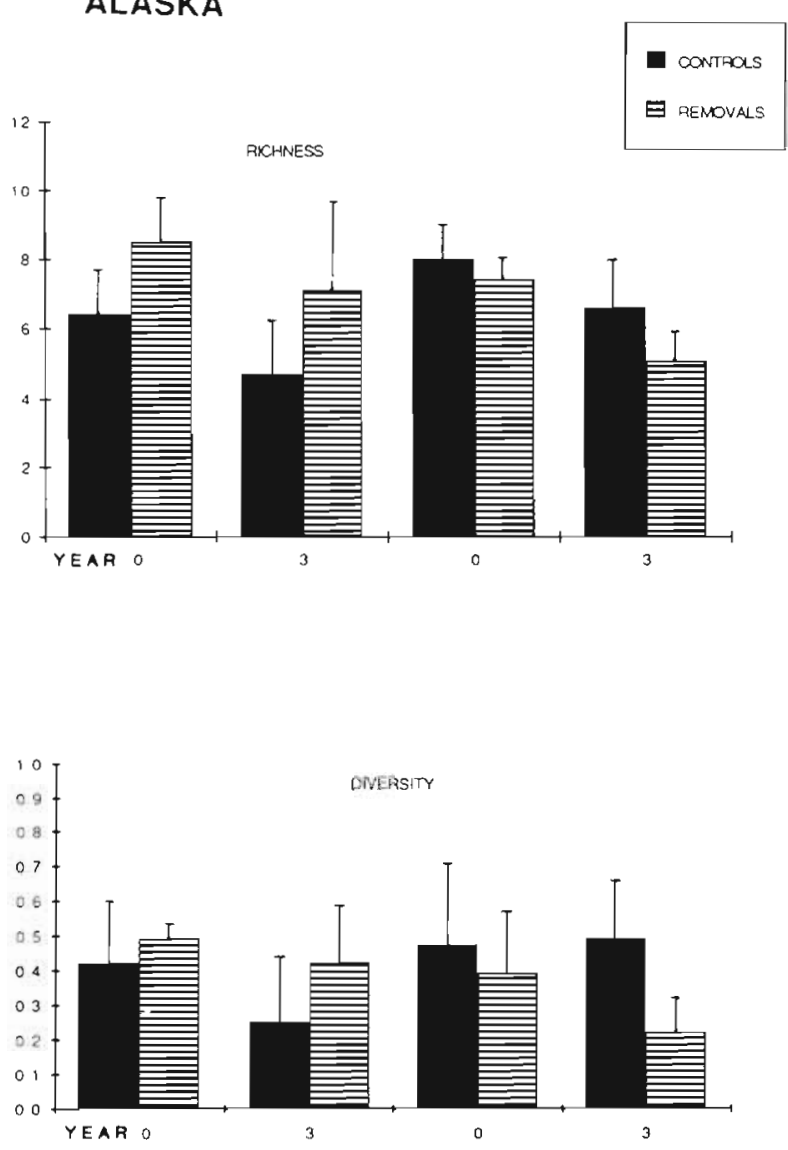

SITE A

SITE B

\section{WASHINGTON}

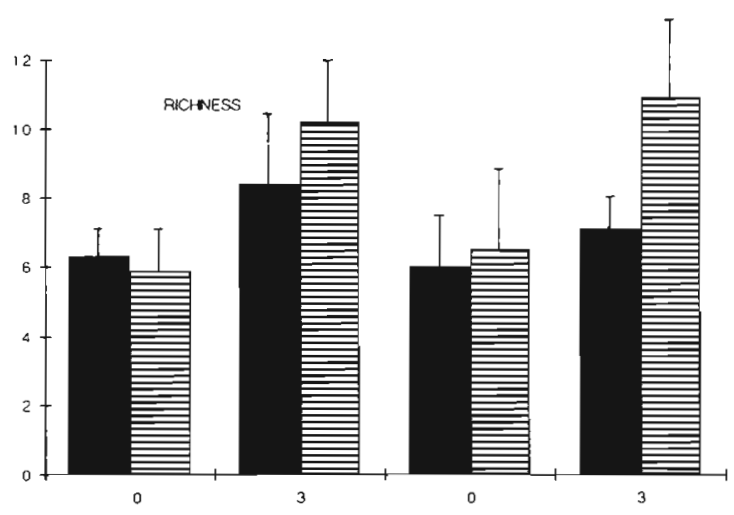

Fig. 3. Levels of algal richness and diversity in experimental and control areas. Algal richness is the mean number of species (or taxa, for species such as crustose corallines that could not be identified in the field) per quadrat. Erect algal diversity uses a Shannon-Wiener index on the proportions of the total cover of erect macroalgae on one date that were contributed by each taxon. For each mean value $1 \mathrm{SD}$ is given. $N$ as in Fig 1 
to-year changes in abundance, leading to great patchiness both among areas and among years (Fig. 2).

Responses of all other erect algae are pooled for analysis, since species composition varied with site and tidal height. No one species of 'other algae' was particularly abundant in the chiton removals. In Washington, erect algae at both sites increased (Table 3 ) in percent cover following the removal of Katharina, although the variances were too high for a significant ANOVA comparing changes through time. If the actual percent covers in the removals and controls at Year 3 (Fig. 2) are compared, there is a significant treatment effect (ANOVA, $p=0.02$ ); removal of Katharina leads to higher algal cover. In Torch Bay, the erect algae in the control areas increased in abundance while those in the chiton removals decreased slightly (Table 3 ), leading to a significant effect in the opposite direction from that in Washington. Table 2 shows that this is not because Katharina are avoiding this suite of algae; they appear to consume almost any species available.

Two measures of algal diversity showed very similar patterns following Katharina removal. At the Washington sites, both the number of algal taxa (richness) and a Shannon-Wiener index of the diversity of erect algae (Duggins \& Dethier 1985) increased over the control levels (Fig. 3, Table 3). In Torch Bay, neither measure showed a significant increase (Table 3), and there was no pattern in the changes relating to a treatment effect.

The most common sessile invertebrates in the midlow zone in both Washington and Alaska were barnacles, sponges, bryozoans, and anemones. In Washington, the amount of substratum covered by these invertebrates combined rarely exceeded $15 \%$, and no clear responses to Katharina removal were seen (Fig. 2). In some quadrats there appeared to be increases in bryozoans and spirorbid worms, but these changes were not evident elsewhere. In Alaska, sessile invertebrates were more abundant (Fig. 2), due to the presence of more barnacles (in the higher quadrats) and sponge and bryozoans (lower), but the removal of Katharina did not appear to alter the large spatial and temporal patchiness in abundance seen in these organisms.

The common limpet species present in both areas were Lottia (= Collisella) strigatella, L. pelta, and Tectura (= Notoacmea) scutum (for name changes see Lindberg 1986). In Washington, limpet abundances dropped gradually in the chiton removal areas, until after 2 yr almost none could be found (Fig. 1, also Dethier \& Duggins 1984). In Torch Bay, the data are again confounded by high year-to-year and site-to-site variation, so that no significant changes in limpet biomass were found (Table 3). However, as in Washington, limpets in the chiton removal areas were nearly locally extinct by Year 3 (Fig. 1), although they were still present in the control areas.
The densities of other herbivorous molluscs were low and very patchy both at Pile Point (Duggins \& Dethier 1985) and in Torch Bay (numbers per $\mathrm{m}^{2}$ : Tonicella lineata $8 \pm 16$. Acmaea mitra $<1$, Mopalia spp. $<1$, small $[<0.5 \mathrm{~cm}$ length] unidentified chitons $12 \pm 26)$. No changes in abundance were discernible at either site in either region.

In summary, Table 3 shows that in Washington there were predictable changes in the parameters measured, with the 2 chiton-removal areas always ranking above the 2 control areas. In contrast, in Alaska the changes show either no treatment effects, or effects (e.g. for erect algae) in the opposite direction from those in Washington.

\section{DISCUSSION}

On the shores of Washington state, the chiton Katharina tunicata is a strong interactor (sensu Paine 1980 ) in that pronounced changes occur when it is removed. This has been demonstrated not only in the San Juan Islands (Duggins \& Dethier 1985) but also on the outer coasts of Washington (Paine 1980, 1984, Palumbi 1985) and Oregon (Gaines 1985). Yet in southeast Alaska, despite broad similarities in community composition, changes attributable to the removal of Katharina could not be demonstrated. In contrast to the strong interactive links between Katharina, kelps, and the abundance and diversity of other algae seen in Washington, in Alaska these components seem quite uncoupled from each other. Three years of chiton removals in Alaska produced less change than was visible in Washington after 1 yr (Duggins \& Dethier 1985), and even extending the experiment into a fourth year at one site (A) in Alaska led to no discernible effect (own unpubl. obs.). The relative absence of treatment effects in Alaska cannot be attributed to smaller sample sizes (same as in Washington) or higher variances (variance/mean ratios were generally slightly smaller in Alaska). Both systems are characterized by high variation among quadrats for most parameters (Figs. 1 to 3), but only in Washington does Katharina exert a clear controlling effect on these parameters.

The most striking difference in community response involved the kelps. In Washington, the perennial brown alga Hedophyllum sessile increased in abundance following Katharina removal and was accompanied, after 2 to $3 y r$, by a variety of other kelps. The result was a multilayered algal canopy. In Alaska, the dominant low intertidal alga is the kelp Alaria marginata, an annual which must survive vulnerable gametophyte and small sporophyte stages each year. Abundance of Alaria (the predominant 'large brown' in Fig. 2) was greater in only one of the chiton removals 
relative to its adjacent control (Fig. 2), and at both sites Alaria was patchy and highly variable from year to year; each fall, the kelp assemblage was 'reset' to zero. Hedophyllum, on the other hand, persists through the year or can regrow from holdfasts following a disturbance, thus providing year-to-year continuity to the algal assemblage; it is capable of dominating space in the absence of Katharina. Norton (1978) found a similar difference in the ecological success of an annual and a perennial kelp in Lough Ine; both kelps are susceptible to siltation and thus can become established only occasionally, but once the perennial has recruited, it persists for many years.

We cannot explain the lack of increase in abundance of other erect algae following Katharina removal in Torch Bay. In Washington, even though smaller erect algae were somewhat suppressed by the canopies of kelps (Duggins \& Dethier 1985), they showed increases in abundance and diversity following release from grazing pressure (Figs. 2 and 3). In Alaska, despite the similar reduction in grazing pressure and despite the absence of a perennial brown algal canopy, the erect algae did not increase (as they did in the controls over the same period). Compensatory grazing by other herbivores did not occur (see below), and resources (space and light) appeared to be available. Even the most dense Alaria canopies did not suppress the other algae (e.g. Removal A, Year 3: Fig. 2). Other possible explanations for the lack of algal response are that: (1) Recruitment of these species may occur rarely, either because spores are not available every year or because sporelings encounter adverse biotic or abiotic conditions. Lewis et al. (1982) note that recruitment failure or variability can be seen both at the geographic limits of a species' range and in areas where annual climatic variability is high. (2) Other sources of disturbance (besides Katharina) may remove juveniles or adults of these algae; these could include waves, freezing conditions, or other grazers that we do not observe at low tide. We do not have the data to evaluate the roles of these additional processes in regulating the community.

In Washington, limpet numbers in the Katharina removals declined over $2 \mathrm{yr}$, probably as a result of decreased microalgal food and foraging space on the rock with increased macroalgal cover (Dethier \& Duggins 1984). Whiplash by large plants may also have reduced limpet recruitment. Lewis \& Bowman (1975) found that limpets have difficulty recruiting under an algal canopy. In Alaska, limpet abundances were much more variable but again showed a tendency to decline (Fig. 1), even though foraging space always seemed available. Diatom abundance was not quantified; it is possible that microalgae were not abundant enough to support large limpet populations in the areas cleared of chitons. Whiplash by Alaria may have reduced limpet recruitment. Whatever the mechanism, this experiment provides another example where the presence of a large grazer facilitates the survival or feeding of a small one (see also Ayling 1981, Duggins 1981, Himmelman et al. 1983, Verlaque 1984).

In summary, Katharina removal in Torch Bay did not cause a predictable, large-scale shift in community composition as it did in Washington. Despite the great biomass of grazers in the low intertidal zone, herbivory is apparently not the dominant structuring process. The Alaskan system is characterized by high site-to-site and year-to-year variability, due in part to the presence of an annual vs a perennial kelp, but perhaps also to unpredictable recruitment and/or frequent physical disturbance.

The difference in community role played by Katharina in these 2 locations leads us to suggest that caution must be used when generalizing about a given strong interaction. The existence of a strong interaction at one site is no guarantee that it will exist at all sites or times, even when the same consumers are present. Paine (1980) has similarly noted that Pisaster ochraceus, a strong interactor in Washington, appears to be 'just another starfish' in Alaska. On a larger scale, Moreno \& Sutherland (1982) demonstrated that although North American and southern Chilean kelp beds contain many of the same sorts of organisms, they are structured very differently; sea urchins and their predators do not play the same controlling roles in Chile that they do to the north. Terrestrial parallels likely exist, but field experimentation across a broad geographical or temporal range is necessary to identify them.

Acknowledgements. We gratefully acknowledge the logistic support and access to Torch Bay supplied by Glacier Bay National Park, especially by crews of the R.V 'Nunatak' Many friends helped with field work under difficult conditions. Earlier versions of the manuscript were improved by Drew Harvell, Jane Lubchenco, Bob Paine, John Pearse, and several anonymous reviewers. Funding for the research was provided in part by a Sigma Xi Grant-In-Aid, and writing was supported by NSF grants DPP 8609796 (DOD) and OCE 8600262 (MND).

\section{LITERATURE CITED}

Ayling, A. M. (1981). The role of biological disturbance in temperate subtidal encrusting communities. Ecology 62 $830-847$

Dethier, M. N., Duggins, D. O. (1984). An 'indirect commensalism' between marine herbivores and the importance of competitive hierarchies. Am Nat 124: 205-219

Duggins, D. O. (1980). Kelp beds and sea otters: an experimental approach Ecology 61: 447-453 
Duggins, D. O. (1981). Interspecific facilitation in a guild of benthic marine herbivores. Oecologia (Berl.) 48: 157-163

Duggins, D. O., Dethier, M. N. (1985). Experimental studies of herbivory and algal competition in a low intertidal habitat. Oecologia (Berl.) 67. 183-191

Dunham, A. E. (1980). An experimental study of interspecific competition between the iguanid lizards Sceloporus merriami and Urosaurus ornatus. Ecol. Monogr. 50: 309-330

Gaines, S. D. (1985). Herbivory and between-habitat diversity: the differential effectiveness of defenses in a marine plant. Ecology 66: 473-485

Hairston, N. G. (1980). The experimental test of an analysis of field distributions: competition in terrestrial salamanders. Ecology 61: 817-826

Himmelman, J. H., Cardinal, A., Bourget, E. (1983). Community development following removal of urchins, Strongylocentrotus droebachiensis, from the rocky subtidal zone of the St. Lawrence Estuary, Eastern Canada. Oecologia (Berl.) 59: 27-39

Lewis, J. R., Bowman, R. S. (1975). Local habitat-induced variations in the population dynamics of Patella vulgata $\mathrm{L}$. J. exp. mar. Biol. Ecol. 17: 165-203

Lewis, J. R., Bowman, R. S., Kendall, M. A., Williamson, P. (1982). Some geographical components in population dynamics: possibilities and realities in some littoral species. Neth. J. Sea Res. 16: 18-28

Lindberg. D. R. (1986). Name changes in the 'Acmaeidae' Veliger 29: 142-148

Menge, B. A. (1972). Foraging strategy of a starfish in relation to actual prey availability and environmental predictability. Ecol. Monogr. 42: 25-50

Moreno, C. A., Sutherland, J. P. (1982). Physical and biological processes in a Macrocystis pyrifera community near Valdivia, Chile. Oecologia (Ber1.) 55: 1-6

Norton, T. A. (1978). The factors influencing the distribution of Saccorhiza polyschides in the region of Lough Ine. J. mar Biol. Ass. U.K. 58: 527-536

Paine, R. T (1966). Food web complexity and species diversity. Am. Nat. 100: 65-75

Paine, R. T (1974). Intertidal community structure: experimental studies on the relationship between a dominant competitor and its principal predator. Oecologia (Berl.) 15: 93-120

Paine, R. T (1980). The third Tansley lecture. Food webs: linkage, interaction strength and community infrastructure. J. Anim. Ecol, 49: 667-685

Paine, R. T. (1984). Ecological determinism in the competition for space. Ecology 65: 1339-1348

Palumbi, S. R. (1985). Spatial variation in an alga-sponge commensalism and the evolution of ecological interactions. Am. Nat. 126: 267-274

Palumbi, S. R. (1986). How body plans limit acclimation: responses of a demosponge to wave force. Ecology 67 : 208-214

Ricketts, E. F., Calvin, J. (1968). Between Pacific Tides, 4th edn. Stanford Univ. Press, Stanford, California

Verlaque, M. (1984). Biologie des juvéniles de l'oursin herbivore Paracentrotus lividus (Lamarck): séléctivité du broutage et impact de l'espèce sur les communautés algales de substrat rocheux en Corse (Méditérranée, France). Botanica mar. 27: 401-424

Wiens, J. A. (1977). On competition and variable environments. Am. Sci. 65: 590-597

Zar, J. H. (1974). Biostatistical analysis. Prentice-Hall, New Jersey

This article was submitted to the editor; it was accepted for printing on September 25, 1988 